\title{
自動設計の現状・問題点・今後の方策*
}

\author{
沖野教郎**
}

好さと好まざるとにかかわらず，コンピュータ化は着 着と進行している.我々の周囲を良く見れば，いたると ころにコンピュータの影を見る。

製造工業においても, 将来, 設計から製造の技術的諸

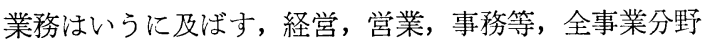
の活動がコンピュータ・エイデドになされるであろうこ とは，ほとえど疑いないとも考えられ，自動設計 (CAD; computer-aided design) もその重要な部分を占めると 予想される。

しかし，現状は将来の完成した状態に対して何％の達 成度であろうか。少なくとも緒の段階は越えたようであ るが，CAD の現況に対する人々の目は意外に厳しい。 自動設計にとって現在は峠を前にしてその登り口を探し ている状態とも言える.

このような認識に立って, 自動設計の現状を見, 問題 点と将来に向かっての方策を考えてみたい。

\section{1. 現状}

\section{$1.1 \mathrm{CAD}$ 主要課題別文献数の分布}

日本科学技術情報センターから出されているSDI サ ービスの CADをキイワードとする文献のうち，1972 年 以降のものを無作為に 1000 文献抽出し, これを主要課 題別に分類すると図 1 の上うになる。厳密な分布調査と はいえないが大体の傾向をつかむことはできる。まず言 えることは $\mathrm{CAD}$ の基礎技術, 周辺技術としての共通課 題に比べて, 特定の機械設備や電子回路など具体問題の $\mathrm{CAD}$ 取扱ったものがはるかに多いことである。ここ
理論, 配置問題, マトリクス構造解析などを中心にすっ きりとまとまっている電子, 建築関倸の CAD に比べて 機械関係は多種多様な対応を必要としているようであ る.

有限要素法 (FEM) の最近の発展は機械関係の CAD にも明るい展望をもたらしているが，図に見るようにそ の交献は CAD の範疇に含まれていないようである。 FEM を自動分割などのプログラムと組合わせて， CAD システムに組込もうとする努力は行わ机ているが，図は その占める割合が比較的小さいことを示している.

基礎周辺技術としてりストアップされた課題澺外に 少ないが，その中では，コンピュータグラフィックス， 自動製図, 自由曲面などの四形処理問題が大きな割合を 占めている.

\section{$1.2 \mathrm{CAD}$ 主要基礎周辺技術の現状}

(1) 対話型システムとCRTディスプレイ：蓄積型 CRT を使った対話システムの出現は, その経済性から $\mathrm{CAD}$ を広く普及させる原動力になろらとしている。ヨ 一ロッパでは最近までテレタイプライタを用いた対話シ ステムが結構使われていたが，現在はこれらがほとえど CRTに代わっている.

図 2 はこの種の対話システムの典型的な例として Appricon 社の IC 設計用の装置一式者示。. 興味深い のは従来のリフレッシュ型 CRT 用のライトペンに代わ って，ディジタイザをうまく使っていることである11. ディジタイザと輝点によって現在位置の指示ができるほ か, 図 3 のような種々なパターンの認識が可能で，これ

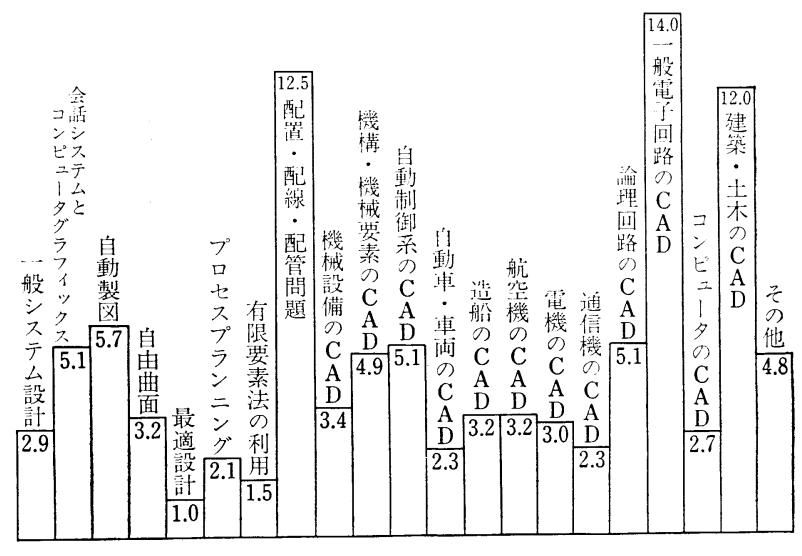

图 $1 \mathrm{CAD}$ 主要課題別交献数の分布（数字は \%)

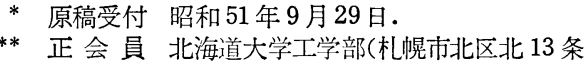
西 8 丁目) 


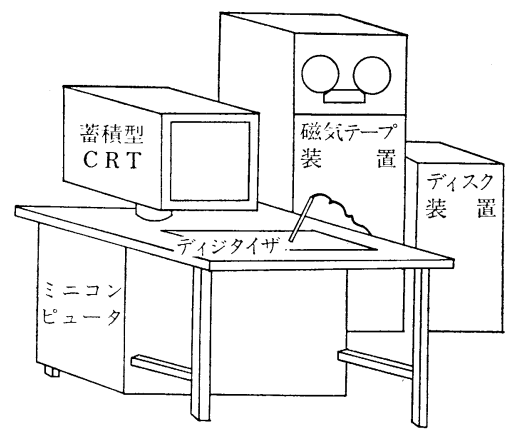

図 2 蓄積型CRTを用いた対話システムの例

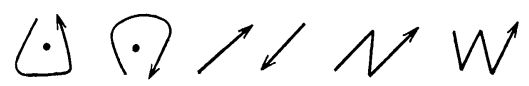

図 3 ディジタイザで認識するパターンの例

と命令語とを対応させることによってかなりスムーズに 対話できる。

一方，リフレッシュ型の CRTを用いた対話 システム もいわゆるコンピュータグラフィックスに関するソフト ウェアの完備とともに，高性能 CAD システムとして， 造船, 建設など大手のメーカを中心に, 実用設計に利用 されている.ライトペンによるピック機能と動画機能は 蓄積型では真似のできないものであるから, 経済性に関 してはなお問題があるとはいえ, 存在価值は十分にあり， 今後の発展莸期待したいものである.

対話システムは上に述べた端末装置だけの問題ではな い. 大型計算機とデータ通信設備, そのソフトウェアを 含めた全システムとして考えられるべきである. 図 2 に 示すようなミニコンとの対話のような小さなシステム， あるい:リフレッシニ型でも, せいぜい数端末を, しか もインラインで使用するような場合の CAD 用対話 シス テムは一応実用に耐えるものができているが，多端末， リモートの大型システムの TSS 対話式 CAD は特殊な 対象に制限するような場合を除いて，まだ実現の運びに は至っていないと考えるべきである.

(2) 問題向き言語： CAD 用の問題向き言語, 例えば, 構造解析用のSTRESS, 電子回路設計用の $\mathrm{ECAP}^{2}$ など は，一応の定着を見て広く使用されている。

かつて，問題向き言語は CADの中心になるものと考 えられ，ブーム的に多数の問題向き言語が作られた時期 もあったが，最近では沉用的な問題向き言語は一部を除 いて消失し，工場固有の専用システムとして作られたも のは, 言語というよりは, 単なる入力フォーマットとし て目立たない存在になりつつある.

$\mathrm{CAD}$ において入力の単純化は最も重要な事項であり,
言語と呼ばれるような文法を伴う入力の約束事は，よほ ど頻繁に利用されるプログラムに対して以外には適当で ないことが理解されて来たようである.

(3) 自由曲面の創成：自由曲面処理に関するここ数 年の傾向は Coons 流の方式に加えて, 新しいブレンディ ング関数として Bézier 曲線3) や B-spline ${ }^{4)}$ が出現した こと, 四辺形パッチのほかに三角形パッチを用いた曲面 創成についても努力が続けられていること，の三つをあ げることができる。

Bézier 曲線やB-spline は，曲面を代表する点群を与 えて，これにスプライン曲面をフィットさせる方式では なく, はじめに曲線, あるい渻を与えて, これを CRTディスプレイ上で修正しながら目的の曲面を作り あげていく方式である。すなわち，これらのブレンディ ング関数はコントロールに便利な曲線を与える点に意味 を持っている、したがって意匠設計を含む CADに新し い道を開くことが期待されている。

三角形パッチは, 従来の四辺形パッチの欠点であった 曲面の境界部分の処理のために, 古くからその必要性を 認識されていたものである。すでにいくつかの研究5161 が行わ机ているが，それらの曲面の性質について確かめ る必要がある。自由曲面はその質を評価する基準があい まいで, fairing という言葉に見られるようにfairであ ることが一つの基準であるが，これはパッチ境界面の接 続など数学的要件を満たしていても必ずしも十分ではな く, 条件によって曲面の一部にうるりが発生するなど容 易でない問題を含えでいるようである.

（4）自動製図：自動製図機のここ数年の努力目標は 高速化であった. 最高速度で $100 \mathrm{~m} / \mathrm{s}$, 最高加速度で $4 \mathrm{G}$ が実現している. 高速化はピニオンラック式では原理的 に実現せず，xynetics 形式またはワイヤ式の平型か，ド ラムタイプが伸びている.

自動製図用のソフトウェアについては, 多数の図形パ ターンをマクロルーチンとして保有し，これを組合わせ て作図する機能がとりこまれるようになって来た。

特定の対象のための問題向き $\mathrm{CAD}$ プログラムの中で も自動作図のソフトウェアは大きなウェイトを占めてい るが，全体にまだまだ工夫の余地があるようである。

陰線処理, 寸法の自動記入などは, 多くの努力が行わ れているものの，まだ解決の状態とは思えない。

（5）有限要素法：FEM 注自動分割プログラムと一体 になって CAD の設計計算部分の中心的プログラムにな ると考えられるが, はじめに述べたように, 今一つ CAD としての形態を整えていないようである。

平面問題に関する FEM 注実用の観点からはほぼ完成 


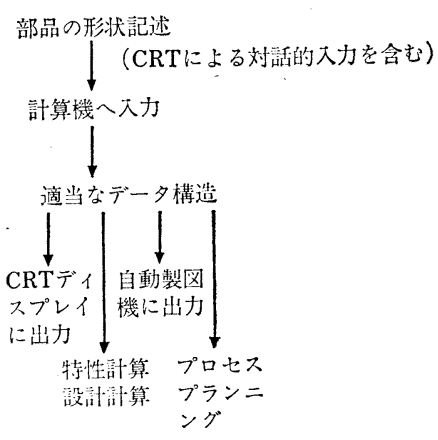

図 4 geometric modeling

の域に達しているように思われ, 現在の研究の中心は応 用数学の問題として, 精度や信頼度に関する精密な詰め に重点が移っている.

しかし，CAD の中でこれを使用するには計算費用の 点で手軽にというわけにはいかない点に問題が残る.

(6) 配置問題：これ注建築関係で注スペースプラン ニング，機械関係ではネスティング（板取り）や配管, 電気関係では, IC の要素配置, 配線, 布線など, 広い 応用範囲をもった問題で，図 1 にも見るように，最近多 数の交献が公刊されている. 筆者はそのすべてについて 調べてはいないが，厳密な意味での最適解を得るような 方法は，たとえ短形板のネスティングのような簡単な問 題でも，まだ提出されてはいないようである.しかし， 実用上の解を得るために，種々巧みな工夫がこらされて いる.

\section{3 新しい課題}

(1) 形状モデル化

これは米国で geometric modeling として最近出発し たことにより注目されるようになった課題である. 図 4 に示すように, 部品の形状記述からスタートして自動作 図，設計計算，プロセスプランニングへと展開すること を将来の目標としている.

CAM-I(Computer-Aided Manufacturing-International, 前身注 APT 協会) の新課題としてこれが設定され， NSF（全米科学財団）の資金を受けて，Rochester 大学 の Voelcker が推進している PADL(Part and Assembly Description Languages ${ }^{7)}$ ) はその中心的存在になってい る.まだ完成したシステムではないが，直方体と円柱の 二つの要素の組合せで，すべての形状を表現しようとす る考え方である.これよりさき 1973 年の PROLAMAT において Braid らは 6 個の基本要素を組合わせる方法 $\left(\mathrm{BUILD}^{8)}\right)$ を, 筆者のグループの TIPS-19) はさらに多 くの基本要素と自由曲面をも組み込めるシステムを発表 している. 最近穂坂らはコンピュータグラフィックスの
分野で高い機能をもった形状 モデル化の手法を発表し た ${ }^{10)}$.

いずれの方法もそれぞれ特徴を持っているが，形状表 現と計算処理の機能注互いに相反する関係にあり, 前者 に重点を置いたTIPS と後者に重点を置いた PADLを 両極端として, 他法との中間にあるものとして位置ゔけ ることもできる、いずれにしてもこの分野は今後の推移 を見守る必要がある。

(2) プロセスプランニング

これ塱して新しい課題ではなく, 古くから CAM と して取り上げられているもので, EXAPT, AUTOPROS などでは，これに大きなウェイトが置がれている。しか し，ここで特にこれを問題にしたのは，最近 CAM-Iで もう一つの新しい課題としてこれがとりあげられ，その 中には CAD 的アプローチが含まれているからである. この課題を要約すれば, 部品の加工順序, 加工方法, 治 工具, 加工条件, 加工機械, 工具経路 (NC) を決定する ことにある.これら沍いに関連しているので同時に決 定する必要がある. EXAPTでも NC 工具経路を与える と加工条件注自動的に求まるが，ここに言うプロセスプ ランニングは，もっとカバーする範囲の広い問題として 考える゙きで, $\mathrm{CAD} / \mathrm{CAM}$ 一貫システムの中で解かれ る問題である.

最近，岩田らは形状記述からスタートするアプローチ を発表し11), 先述の PADL, BUILD, TIPS-1 もプロセ スプランニングを最終段階で含む計画で進められてい る. そのほか, 内外の多数の研究者がこの問題にとり組 んでいるので近いうちに興味ある展開が期待される。

\section{4 最近の工場における CAD}

正確な統計的資料にもとづくわけではないが，最近， 二, 三年の間の機械会社における自動設計システムの製 作はかなり活発である。それぞれの製品に対する専用 $\mathrm{CAD}$ システムであり，いくつかの標準パターンを用意 して, 仕様に対して, その寸法や材料などを決める過程 を自動化することをべースに，問題向きの対応ぶなされ る.

このような専用システムの到達目標は, CAD, CAM のみならず，資材管理，販売管理を含わた総合 EDPS で あり，オーダエントリーシステム ${ }^{12}$ 法その一つの典型で ある。

一方, 有限要素法などを用いた沉用プロセサの蓄積も 着々と進められている。

\section{2. 問 題 点}

ここでCADの現状に対応して問題点を考えてみよ 


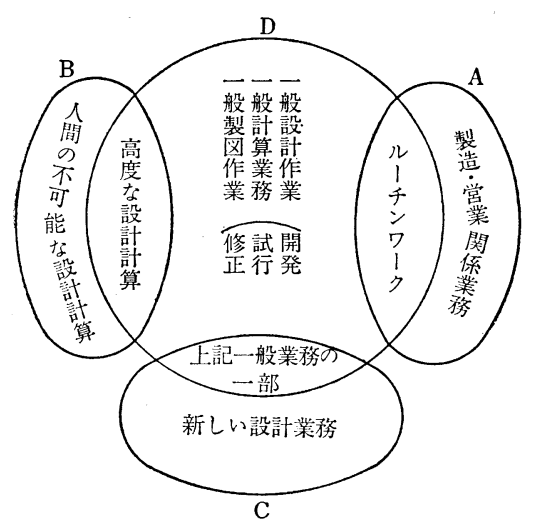

図 $5 \mathrm{CAD}$ と従来の設計業務との関係

う.

\section{1 設計室における業務の変化}

図 5 の中央の円 $(\mathrm{D})$ を, 従来の設計室の業務とすると き, そのうちのルーチンワーク (A) はこ机が尃用システ ムとして CAD 化さ机ることによって，オーダエントリ ーシステムのような形に編成されて, 設計室の業務から 離れる形になっている。一方, 汎用プロセサは高度な設 計計算 (B) のために作られているのが現状であるが，こ れが更に発展して, 従来は行うことの出来なかった精密 設計のための新しい計算が設計室業務に加わることとな って来た．例えば FEMを用いた計算は, 造船, 建築, 原子力容器関倸の設計において, 注文主あるい注規則に よって強制されることも起こってきた。

同じこと注一般業務 (C) についても言えることで, 作 困や，簡単な計算業務が自動化される一方で，それらを 用いた新しい業務，例えば，注文主へ提出用の各種説明 四, サービス図, 環境アセスメントや製造部門で使用す る伝票, 見取図の作成などが追加されることとなった。

これらのこと注必ずしも問題点ではない。むしろ， CADの良い影響であるかも知れないが設計室にとって は，それをこなすだけの準備ができていない場合，問題 点になる。

\section{$2.2 \mathrm{CAD}$ 技能者の発生}

$\mathrm{CAD}$ 技能者とは，丁度 $\mathrm{APT}$ パートプログラマのよ うに CAD 用プログラムのいくつかを受持ち, CRT ディ スプレイなどの機械を操作して，設計者の依頼にこたえ る人たちである。

このような専門技能者は CAD プログラムが増えるに 従って増える. 結局, 設計室とは別に計算専門部が, 多 数のこれら技能者とプログラマとを擁して CADを受持 つことになる。

このような組織の分離は現状では適当と考えられる
が，も乙設計室が旧態のまま残っているとすれば，問題 点として考慮の要があるのではなからうか.

\section{3 設計室の現状}

上述のように, CAD 注計算機室, あるいは計算専門 部において行われ，設計室そのものに変化がなく，設計 者も直接コンピュータを使うことの少ないのが現在の状 態である.

CAD の専門技能者に計算を依頼することもCADでは， あるが, CADの本来の目的は設計者とコンピュータが 一体となって，設計者が自分自身考光るプロセスの中 で、コンピュータの助けを借りることであった。したが って単に計算処理だけでなく, 図形処理が大きなウェイ トを占めるのであり，これを行うに注設計者が直接コン ピュータを操作するべきである。

\section{3. 今後の方策}

はじめに述べたように，コンピュータ化は時代の流れ であるとして，CADを推進するに法今後何をなすべき であらうか。

\section{1 個人用リモートターミナル}

その答えは（筆者の独断的見解に過ぎないが）一口に 言って，設計者にコンピュータを使いやすくさせること につきると思う。そのために，まずハードウェアでは， 設計者の座右に個人用りモートターミナルを設備する必 要がある. 計算機室へ出向いて仕事をするのではなく, 手元にターミナルを引き寄せるわけである.

これを設備するための障害の第一注セントラル計算機 側での通信制御の問題である.ターミナルの多いことを 考劣ると TSS で注制御用に大型計算機が必要となる. 第二の障害はターミナル設備の費用の問題である。休止 時間の極めて大きい設備を設置することに経営者側况難 色を示すことが予想される。

第一の問題には, TSSを捨ててリモートバッチ形式 にすることが一つの解決策である。 CAD はリアルタイ ムでの応答を必ずしも要しない，個人用端末の場合には なおさらである．図6亿電子交換機とバッフォメモリで 構成する電話回線利用の多数の端末のリモートバッチ処 理システムの案を示す．ただ，この場合，設計者側の端 末はリモートバッチであるから，入出力に際して，これ を一時蓄えるメモリを必要とする。CAD のために注図 形出力を必要とするから，そのようなインテリジェント ターミナルを設備するための経済上の問題，すなかち第 二の問題を今後考慮すべきであるが，その構成について は多くの工夫の余地もあるので, 将来の発展を含めた効 果と十分バランス寸るであろう。 


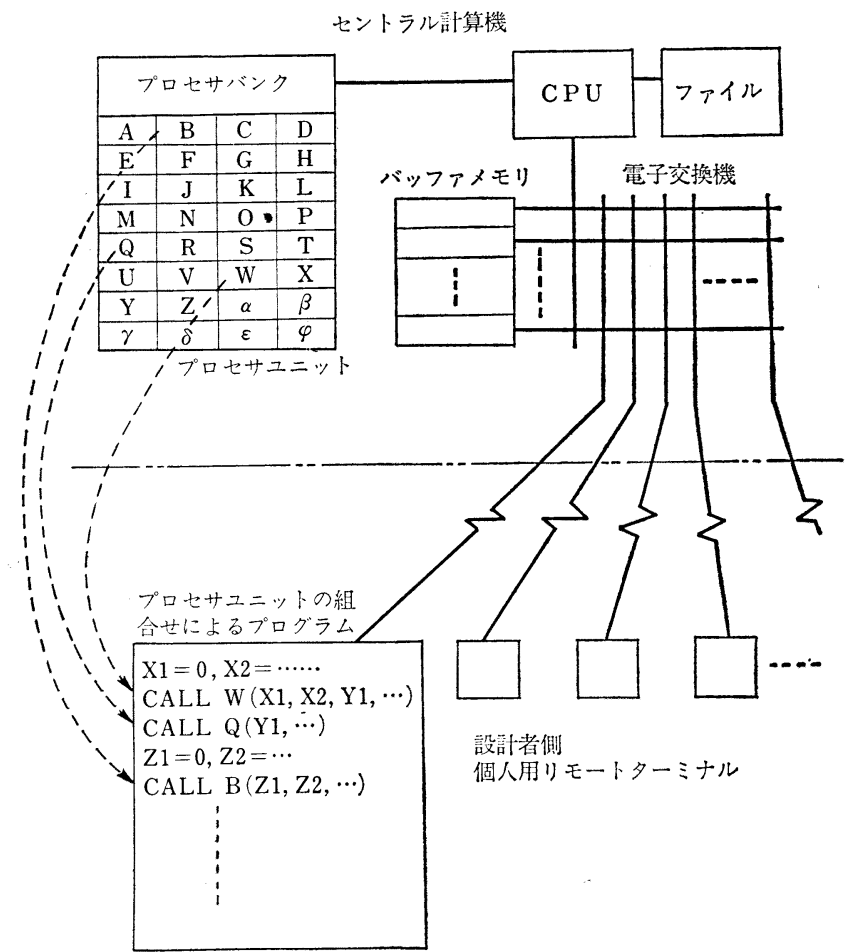

図 $6 \mathrm{CAD}$ 用計算機システム(案)

\section{$3.2 \mathrm{CAD}$ 用プロセサバンク}

次にソフトウェアに関しては, CADの各プログラム をプロセサベースに構成する案を記しておく、これは図 6のように多数のプロセサをフォイル中に準備して抢 き, 設計者はこ秃らのプロセサをCALLして組合わせ, 各引数に值を入力することを主体とするプログラム作成 方式によって，問題に対応するプログラムを容易に作成 できるようにすることが秝らいである。もちろん，バン クに用意するプロセサとそのフォーマットに特別な工夫 を要する。

CAD のシステム設計者は，専用，沉用を問わず，問 題を解くためのプログラムを準備し，これを出来るだけ 容易に使えるようにするために種々な工夫をこらして来 た。例えげ問題向き言語や，CRT を用いた対話システ ムも結局注入力と，プロセサの選択のための工夫である と言える.

それらのプロセサを大きなシステムに組みこえでしま わず, 独立に使用できる形にしておいて, 必要に応じて 自由に組立てる方式が，単純ではあるが，本命ではない かと考えている. 大きなシステムとして利用する場合で も，そ礼学独立な各プロセサで構成することが，将来の 改変のために必要である.

\section{4. あ.とがき}

ここではまず現状を, 主として研究側に立 って総花的に述べ, 次に工場側に立って最近 現れた問題点を重点的に記すと共に, 今後の 方策に関する筆者の考光を付記した。

いわゆる展望記事は必ずしも客観性を必要 としないが，主観的記事であっても，十分な 調査にもとづいて書かれるべきである.しか し， CADの交献は，すでに一人がこれを読 みつくすことは不可能なほどに毎月刊行され ている。 また CADを実行している会社も最 近飛躍的に増大している.

これらの情報を整理し, 組織化するコンピ ニータエイデドシステムが欲しい，設計情報 の整理が設計システムの出発点であるから， この問題は $\mathrm{CAD}$ 自身の問題である.

\section{引用文 献}

1) AGS System User's Manual, Applicon Co., U. S. A., (1973).

2) R.W. Jensen \& M. D. Lieberman: IBM Electronic Circuit Analysis Program, Prentice Hall, N. J., (1968).

3) P. E. Bézier: UNISURF System, Principles, Programme, Language, Proc. 2nd PROLAMAT Conf., (1973).

4) W. J. Gordon \& R. F. Riesenfeld: B-Spline Curves and Surfaces, Computer Aided Geometric Design, Academic Press, New York \& London, (1974) 95.

5) R. E. Barnhill: Smooth Interpolation over Triangles, Computer Aided Geometric Design, Academic Press, New York \& London, (1974) 45.

6）松本英二, 沖野教郎: 自由曲面の点群処理汇関する研 究, 昭和 49 年度精機学会北海道支部大会前刷 (1974).

7) H. B. Voelcker, A. A.G. Requicha et al.: PADL Tech. Memo, Univ. of Rochester, (1974).

8) I. C. Braid \& C. A. Lang: Computer-Aided Design of Mechanical Components with Volume Building Bricks, Proc. 2nd PROLAMAT Conf., (1973).

9) N. Okino, Y. Kakazu \& H. Kubo: TIPS-1; Technical Information Processing System for Computer-Aided Design, Drawing and Manufacturing, Proc. 2nd PROLAMAT Conf., (1973).

10）木村交彦，穂坂 衛：幾何モデルの生成と処理につい ヶ, MMS, 24, 2 (1976).

11) Y. Kakino, K. Iwata et al.: A New Method of Parts Description for Computer-Aided Production Planning, Proc. 3rd PROLAMAT Conf., (1975).

12） 三船孝雄：電動機生産にみるオーダーエントリーシステ 公, 日本機械学会誌, 78, 685 (1975) 1115. 